\title{
Postcolonialism and national HRD: Understanding contemporary challenges to skills development in sub- Saharan Africa
}

DOI:

10.1080/13678868.2019.1612651

\section{Document Version}

Accepted author manuscript

Link to publication record in Manchester Research Explorer

Citation for published version (APA):

Ekuma, K. (2019). Postcolonialism and national HRD: Understanding contemporary challenges to skills development in sub-Saharan Africa. Human Resource Development International . https://doi.org/10.1080/13678868.2019.1612651

\section{Published in:}

Human Resource Development International

\section{Citing this paper}

Please note that where the full-text provided on Manchester Research Explorer is the Author Accepted Manuscript or Proof version this may differ from the final Published version. If citing, it is advised that you check and use the publisher's definitive version.

\section{General rights}

Copyright and moral rights for the publications made accessible in the Research Explorer are retained by the authors and/or other copyright owners and it is a condition of accessing publications that users recognise and abide by the legal requirements associated with these rights.

\section{Takedown policy}

If you believe that this document breaches copyright please refer to the University of Manchester's Takedown Procedures [http://man.ac.uk/04Y6Bo] or contact uml.scholarlycommunications@manchester.ac.uk providing relevant details, so we can investigate your claim.

\section{OPEN ACCESS}




\section{Postcolonialism and national HRD: Understanding contemporary challenges to skills development in sub-Saharan Africa}

\section{Kelechi Ekuma}

Global Development Institute, The University of Manchester, Manchester, UK

School of Environment, Education and Development

The University of Manchester

Oxford Road, Manchester, M13 9PL

kelechi.ekuma@manchester.ac.uk

\section{Author Note}

Kelechi Ekuma is a lecturer in Management, Governance and Development Leadership at the Global Development Institute, The University of Manchester, UK. He holds a PhD in Development Policy and Management from the same University. Kelechi's research interests are situated within the broad areas of public sector governance, national HRD, knowledge for development (K4D), capacity development and institution restructuring, with a particular focus on less developed countries. 


\title{
Postcolonialism and national HRD: Understanding contemporary challenges to skills development in sub-Saharan Africa
}

\begin{abstract}
This paper argues that national human resource development (NHRD) practices, policy imperatives and challenges in sub-Saharan Africa (SSA) are linked to colonial experiences and coloniality. In doing this, the essay provides a brief overview of the intersections between postcolonialism and NHRD theory and practice, arguing that postcolonial insights can help overcome the ahistorical nature that characterizes much NHRD theorizing and also its reification. By demonstrating how current challenges to education and skills development in SSA are linked to colonial heritage and coloniality, the paper seeks to stimulate HRD theorists and practitioners to think differently and work beyond dominant neo-liberal constructs and taken-for-granted assumptions about NHRD in postcolonial contexts. The paper also argues for the decolonization of NHRD and proposes some ideas about how knowledge about NHRD theory and practices might be made global and inclusive, thereby contributing to a tradition of paradigmatic critique in HRD theorizing.
\end{abstract}

Keywords: NHRD, postcolonialism, education, skills development, sub-Saharan Africa 


\section{Introduction}

The national human resource development (NHRD) process is an approach that enhances and supports the impact that people can have at both organizational and broader societal contexts (McGuire, 2014). As Collins et al. (2017) argue, NHRD is primarily about how to organize opportunities for sustainable change and how to imagine and deliver processes that can underpin both organizational and societal transformation. NHRD's emphasis on societal transformation highlights the crucial need to promote a more coherent and robust dialogue between the concept and postcolonial studies. Indeed, it is now increasingly recognized that postcolonialism shares a close affinity with NHRD in the sense that both concepts seek to promote a people-oriented, integrated and comprehensive frameworks that can help advance inclusive development agenda, including the promotion of human well-being and the eradication of inequalities and social injustices (Lee, 2017; Syed \& Metcalfe, 2017).

Despite this realization, the relationship between NHRD and postcolonialism remains less well explored. It appears that the two concepts have been unwittingly ignoring each other's dialogue. Much of the postcolonial studies, for instance, have mainly concentrated on 'tracing the patterns of colonial retreat and in examining the cultural legacy of its aftermath' with little consideration for NHRD issues (Strongman, 2014: 1352). Scholarly studies on NHRD have also been predominantly Western-driven and underpinned mainly by a neoliberal epistemology which often assumes that organizational structures are universal and premised on neo-liberalism (Castells, 2010; Lee, 2017). This development raises concerns about the relevance of existing accounts and knowledge of NHRD as a tool for human development and social transformation in postcolonial contexts like sub-Saharan Africa (SSA) and much of the developing world, because it is problematic to assume that there is one universal perspective from which NHRD can best be understood (Tikly, 2001). 
It is also the case that apart from few studies (e.g. Hasler et al., 2006; McLean, 2006; Arthur-Mensah \& Alagaraja, 2018; Alagaraja \& Wang, 2012, etc) much of the recent literature on NHRD and social transformation in postcolonial contexts has been weighted towards economic concerns, particularly of MNCs or international organisations to the detriment of social concerns including gender, identity, language, norms, culture and power relations. This is a significant gap in NHRD theorizing, especially because the issues highlighted above play crucial roles in shaping NHRD policies and are also central to our understanding of the context within which national policies are formulated and implemented. Inadequate understanding of the contextual subtleties influencing the NHRD process means that strategically important questions are often left out in the NHRD policy processes in many developing countries (DCs), leading to a failure to explicitly link skills development efforts to local priorities (Miller, 2010; Otoo et al., 2009). Perhaps, this helps explain why the outcomes of several efforts aimed at improving national human resource capabilities in many SSA countries and other DCs have persistently fallen short of expectations (World Bank, 2018).

Against this backdrop, it becomes crucial to promote closer dialectical affinities between postcolonialism and NHRD by integrating literature from both concepts (Lee, 2017; Syed \& Metcalfe, 2017). Although some HRD theorists and scholars have begun to incorporate a postcolonial perspective into their work (e.g. Nkomo, 2011; Syed \& Metcalfe, 2017; Lee, 2017; Syed et al., 2018), this emerging literature has remained marginal, and the implications of recent developments in postcolonial scholarship for NHRD is still underexplored. By focusing on approaches to NHRD, particularly the policies that inform education and skills development in developing and postcolonial contexts, this article demonstrates that a postcolonial reading of NHRD is crucial and 
indeed overdue. It is imperative to stress that while the analysis in this paper will contribute towards illuminating the relevance of postcolonial theory for understanding the NHRD process in Africa and other developing/transitioning postcolonial contexts, the main focus will be on SSA.

The focus on SSA is in recognition that while there are several similarities between many postcolonial, low-income countries in terms of their development profile, there are also remarkable differences in the specific ways in which different countries and regions of the postcolonial world have responded to their developmental challenges, including approaches to NHRD (Tikly, 2001). In the specific case of SSA for instance, institutional and structural constraints, governance challenges, reform failures, growing inequalities and the low level of education, means that the focus of NHRD has tended to be towards 'capacity development' (whether human or institutional) (Ekuma, 2015). While it is acknowledged that the colonial experience varies from one SSA country to another, skills gaps, capacity constraints, and inadequacies in the educational systems seem to be critical features that have remained prominent and consistent across most SSA countries (UNESCO, 2011, ADB, 2018).

The scale of these challenges and its consistency across countries of SSA are perhaps, best illustrated by the region's illiteracy level, which is the highest of any region in the world including other developing regions (UNDP, 2018; World Bank, 2018). Despite recent expansion in SSA's education system, the World Bank (2018) estimates that only about $64 \%$ of adults aged 15 and above are literate in the region compared to South Asia (71\%), Latin America and Caribbean (94\%) and East Asia and Pacific (96\%). The constraints in the educational system of many SSA countries have arguably contributed to the region's inability to produce enough job-ready young people, who have the skills to fill the jobs that are being generated in the region, 
resulting in rising unemployment and threats of social insecurity by jobless youths (Ekuma, 2015). These insights underscore the urgent need to rethink the strategies for skills development in SSA and help position the context for discussing renewed approaches to NHRD in the region.

Overall, the postcolonial perspective to NHRD explored in this paper, seeks to stimulate HRD theorists and practitioners to think differently and work beyond dominant neo-liberal constructs and taken-for-granted assumptions about NHRD. The primary objective is to help refocus attention to the often subtle, but enduring stratified structural systems and unequal power relations that continue to perpetuate multidimensional inequalities and undermine the development story in many developing and postcolonial contexts. In doing so, the essay draws on historical literature on education and skills development in SSA (e.g. Lulat, 2005; UNESCO, 2015) and policy documents related to NHRD in the region (e.g., Continental Education Strategy for Africa-CESA, 2016 ) to highlight the epistemologies of colonial inheritances and coloniality, highlighting how these have combined to shape the NHRD story in contemporary SSA. The analyses here support more sceptical readings of the current NHRD story in SSA and lead to a conclusion that a postcolonial interpretation of NHRD offers a more nuanced perspective for understanding the current skills development challenges facing SSA than mainstream explanations that do not pay sufficient attention to the colonial experience and coloniality.

The rest of the paper is developed in four main parts. The section that follows briefly explores the meanings of NHRD in a globalizing world, positioning the need for a postcolonial perspective to NHRD theorizing in postcolonial and developing contexts. Section three reviews the state of NHRD in SSA, focusing on the history of education and skills development in the region since pre-colonial periods. Section four briefly 
highlights the nature and dynamics of the skills challenges in contemporary SSA, with an additional focus on how the colonial experience shaped and continues to shape the NHRD story in contemporary SSA. This approach helps unravel the specific ways in which 'migrated structures' (a term which captures the interplay between endogenous cultural patterns and colonial heritage) impact NHRD theory and practice in SSA. It also helps reveal how the non-deconstruction of inherited colonial institutions constitute the historical roots of the region's current skills challenges, which is discussed in section four. The paper concludes by arguing for the deconstruction and decolonization of NHRD theory and practice to promote an inclusive global knowledge about the subject that is both culturally and contextually sensitive. A global NHRD knowledge would arguably help place historically marginalized parts of the world at the centre, rather than at the periphery of the education and skills development discourse.

\section{NHRD and skills development in a globalizing world: towards a postcolonial interpretation}

It is now universally recognized that the availability of skilled individuals and quality national human resources are central to future global economic competitiveness and that a country's most valued asset is its human resources (Leopold et al., 2017; Word Bank, 2018). Although NHRD has defied a univocal definition, the concept is widely acknowledged as a planned and coordinated participatory process that promote knowledge and capacity development of individuals and groups to effectively influence the processes that directly affect their lives (Kim, 2012; UNGA, 1995; Cunningham, Lynham, and Weatherly 2006; Garavan et al., 2018). As McLean and McLean (2001: 10) have since pointed out, HRD whether at organisational or national level, 'is any process or activity that, either initially or over the long term, has the potential to develop...work-based knowledge, expertise, productivity, and satisfaction, whether for 
personal or group/team gain, or the benefit of an organization, community, nation, or ultimately the whole of humanity'.

Cho and McLean (2004) provide a more specific definition of NHRD as the strategies, programs, and policy initiatives geared towards capability and capacity development of human resources at the national level. Framed this way, it becomes evident that NHRD is not an end itself, but a means to an end, and could be positioned as a process that helps nation-states improve the quality of their human resources through synthesized and strategic skills and capability development initiatives (Alagaraja \& Gittens, 2016; UNGA, 1995). The importance of NHRD to national development cannot be overemphasized, considering that in any organization (whether public or private), it is the human element that commands, directs, organizes, controls and maximizes other factors of production (De-Silva, 1997; Ekuma, 2015).

What is more, globalization, advances in information and communications technologies (ICTs) have also increased the demand for intelligent workers who can extract the most out of technology, as well as for people at higher levels to create and adapt technology to new uses (UN, 2014; McGuire, 2014). The impacts of NHRD are evident in the much-publicized rapid development achieved over a short period by countries such as Singapore, Hong Kong, South Korea, Taiwan China, and earlier by Japan (Oh et al., 2017; Cunningham et al., 2006). It is now generally acknowledged that besides other factors, the development success stories of these countries are mainly a function of the advancement of endogenous capacities achieved through aggressive and strategic investments in national human resources (Dauda, 2010; Ekuma, 2015).

When considered in developing and transitioning contexts, the idea of NHRD, assumes even a more critical dimension and extends beyond just organisational, skills and capability issues to include broader societal concerns such as health, gender, 
culture, community development, and a host of other developmental considerations that have not typically been perceived as 'human capital' investment (McLean, 2004; McLean, 2006). However, while NHRD encompasses a wide range of dimensions, the term is used in this paper to cover mainly education and skills development. While other aspects of NHRD might be used for illustrative purposes, the main focus here is on education and skills development, because these dimensions of NHRD are crucial in the process of acquiring and increasing the skills and experiences of individuals which are critical in advancing rapid socio-economic and human development. The continuing shift towards a knowledge-based economy at the global level means that these two dimensions of NHRD will continue to be key policy issues both in developed and developing countries (World Bank, 2018). This paradigm shift engendered largely by rapid globalization has led to a new world order which places a premium on innovativeness, versatility, flexibility, self-development and massive investment in human resources (Marquardt \& Berger, 2003).

Globalization, itself a highly contested and polarized concept, is widely understood 'as a process in which there is a growth in the functional integration of national economies' (Edward \& Rees, 2006: 5). While the outcomes of this pervasive integration remain uneven and are often mired in emotive debates, what is hardly debated is that a knowledge-driven global economy has emerged, in which distinct national boundaries and economies are becoming increasingly irrelevant (Edwards \& Rees, 2006). These changes, which are driven by advances in ICTs and the activities of transnational corporations, means that ideas and knowledge are transmitted and exchanged pervasively across all contexts (Ashenfelter et al., 2018; Fukuyama, 1993). While this development admittedly has many benefits, it has also arguably led to the 
emergence of westernization as the dominant knowledge system in the formulation and implementation of development policies (Goldin \& Reinert, 2012; Ekuma, 2015).

It is important to stress that external influences can only become meaningful and embedded in a given context only once they have been domesticated or institutionalized and acted upon by local groups and individuals (Hayden, 2008). This implies that national development policies, including NHRD, are shaped by the hybridization of socially constructed indigenous values, as well as the hegemony of dominant knowledge systems engendered by global power relations (Jackson, 2004). These global power relations are however almost always unequal, and this helps explain why expert knowledge about NHRD is mainly driven by dominant western theories and neoliberal practices that are assumed to be universally applicable (Lee, 2017).

Indeed, Samoff (1999) has since illustrated how, through the global diffusion of Western ideas through colonialism and coloniality, thinking about education and skills development has become almost universal. This universalism is illustrated by the dominance of neoclassical paradigms and approaches in NHRD policy planning across the world. Influenced by the activities of international development agencies such as the World Bank and the International Monetary Fund (IMF), the broader development processes are also interpreted in similar ways, tending to steer approaches to NHRD into the same neoliberal direction (Castells, 2010; Jack \& Westwood, 2009; Kenny \& Clarke, 2010).

In recent years however, the evident profound failings of neoliberal theories in practice, particularly rising poverty levels and widening inequalities across the world, have led to calls for a better understanding of the interlocking factors of context, perceived developmental needs, institutional requirements and development history in policy initiatives, including NHRD (Kenny \& Clark, 2010; Nkomo, 2011). These calls 
reinforce the need to promote a more systematic dialogue between NHRD and postcolonialism, given the latter's sensitivity to socio-cultural and geopolitical peculiarities and how they shape knowledge, practices, attitudes, and learning.

\section{Postcolonial theory and NHRD}

Postcolonialism is a process rather than a descriptive or evaluative term (Hickling-Hudson, Matthews \& Woods, 2004). The term has been used extensively in a wide variety of ways, and there is much debate concerning its precise meaning or what it precisely represents (Strongman, 2014; Carl, 2006). These debates have centred mainly on issues relating to the nature of postcolonialism in contemporary contexts and the extent to which the concept has been an emancipatory tool or indeed complicit in legitimizing the contemporary structures of global capitalism and dominant western knowledge system (Tilky, 1999; Rizvi et al., 2006). There are also disputes regarding whether or not postcolonialism is too homogenizing to be a useful tool for understanding the experiences and structural transformations of transitioning and postcolonial contexts, especially given their unique histories, diverse experiences, and hybridity (Tilky, 1999, Carl, 2006).

Debates over postcolonialism thus represent genuine theoretical and political contestation; but they also involve a range of conceptual confusions about the scope of its major claims (Rizvi et al., 2006). Several scholars (e.g., Young, 2009; Strongman, 2014; McLeod, 2013; Rizvi et al., 2006, etc.) have provided an almost exhaustive account of these debates, and an emerging consensus seems to be that postcolonialism helps to make visible the covert forms of oppression still at play against most of the global South. The concept advocates for ideological, political, economic and cultural liberation of formally colonized countries (Young, 2009). As Tikly (2001) points out, postcolonialism represents a worldview which reflects a historical consciousness that is 
highly critical of the exploitation of countries in the developing world by their colonizers. It also describes a reimagining of the world order or 'shift in the cultural, political and economic arrangements that arise from the experiences of European colonialism both in former colonized and colonizing countries' (Tikly, 1999: 605).

Postcolonialism offers a useful tool for a critical discussion of NHRD issues, especially the dynamics of education and skills development in formerly colonized countries, because of its utility in exploring and understanding local/contextual dynamics (Hickling-Hudson et al., 2004; Carl, 2006). A postcolonial perspective to understanding local situations is especially relevant in the context of DCs and SSA in particular, because the concept makes visible the history and legacy of European colonialism, enabling us to understand how colonial legacy continues to shape the region's contemporary political, socio-cultural and economic institutions (HicklingHudson et al., 2004; Ndhlovu, 2016). As Prakash (1994: 1475) has since pointed out, postcolonialism promises 'a radical rethinking of knowledge and social identities authored and authorized by colonialism and western domination.'

These insights highlight the potential explanatory power of postcolonialism in advancing our understanding of the contextual conditions that shape the NHRD process in SSA, because of the primacy it gives to local history and the dynamics of global unequal power relations in understanding national policies, including NHRD. Analytically, a postcolonial perspective to NHRD helps draw our theoretical attention to how global inequalities are perpetuated not only through the distribution of resources, but also through colonial modes of representation, and knowledge production (Said, 2003). As Young (2009: 24) notes, postcolonialism seeks 'to change the way people think, the way they behave, to produce a more just and equitable relationship between different peoples of the world.' 
A postcolonial approach to understanding NHRD positions education and skills development as a socially constructed process, which is shaped by history and local conditions (Syed \& Metcalfe, 2017). This perspective contrasts with dominant views on NHRD, which mostly interpret education and skills development as behavioural, technical and apolitical processes, with little consideration given to the socio-cultural and geopolitical peculiarities and how they shape knowledge production, policy practices and attitudes to learning (Lee, 2017). Postcolonialism instead views NHRD as messier political process embodying a set of global power relations and other interlocking contextual factors including socio-economic and political considerations (Lee, 2017). This implies that NHRD, just like other aspects of the development process should ideally be analyzed and understood in terms of people and their local contexts (Elliott \& Turnbull, 2004).

When considered in the context of this paper, a postcolonial analysis of NHRD is a converging dialogue that seeks to understand the historical, political, socio-cultural, economic and institutional characteristics of SSA, and how these features combine to shape current NHRD policies and processes within the region. The value of taking this approach is that it makes it possible to explore some of the underlying factors that shape the NHRD policy-making and implementation processes, because the historical, social and cultural legacies of a group can have a strong and lasting effect on institutions, power structures/relations, ideologies and values that people hold (Moncrieffe \& Luttrell, 2005). It is against this backdrop that it becomes crucial to critically explore NHRD in SSA from a postcolonial perspective, to illuminate the nature of the current education and skills development problems facing the region. This type of analysis is a useful starting point in promoting inclusive NHRD knowledge and reconstructing 
renewed approaches to understanding education and skills development in SSA, and other postcolonial contexts.

\section{NHRD in postcolonial context: the sub-Saharan Africa experience}

One of the essential truisms about the process of NHRD is that it is a system (McGuire, 2014). This means that all components for developing and managing people should ideally be interrelated and integrated within a given context (Ekuma, 2015). It is also the case that like other development policies, NHRD policy, particularly education and skills development policies are closely connected to their socio-political, cultural and historical context and to the narratives and ideas that inform them. In the case of SSA for example, the current state of NHRD systems cannot be understood in any meaningful sense without due consideration for colonial legacy and coloniality.

A focus on coloniality is especially relevant for understanding NHRD in SSA considering Maldonado-Torres' (2007: 243) argument that the concept represents the 'long-standing patterns of power that emerged as a result of colonialism, that define culture, labour, intersubjectivity relations, and knowledge production well beyond the strict limits of colonial administrations.' Coloniality thrives on globalization and 'is maintained alive in books, in the criteria for academic performance, in cultural patterns, in common sense, in the self-image of peoples, in aspirations of self, and so many other aspects of our modern experience' (Maldonado-Torres, 2007: 243). Given these insights, it becomes crucial then to understand the historical contexts of education and skills development policies in SSA to help place current discourses, practices, and limitations within its right contextual and historical perspectives. 


\section{Colonialism, education and skills development in SSA}

Contrary to claims by the colonial literature that Europeans brought education to SSA, the history of education and skills development in the region dates back to the precolonial era, through the pioneering efforts of indigenous African scholars and philosophers (Lulat., 2005). Education in Africa during this period was geared towards preserving the heritage of the community by helping members to adapt to the physical environment as well as advance community institutions, laws, language, and values inherited from the past (Lulat, 2003; Nyanchoga, 2014). Education and skills development in pre-colonial SSA were communal in nature, transferable from generation to generation and continuously modified to meet changing societal needs (Nyanchoga, 2014). For instance, the transformation from food and hunting economies to food producing economies with its associated skills change, was based on the societal need to meet the demand for food in order to sustain future generations (Lulat, 2003).

Education and skills development in pre-colonial Africa were therefore, about adaptation, self-reliance and sustainability of societies (Nyanchoga, 2014). Important centres of learning such as Sankore University and the University of Timbuktu in present-day Mali were set up to help facilitate this process. These centres eventually became important institutions of knowledge production and great intellectual nucleus that focused on Afrikology as well as the advancement of science and technology (Nyanchoga, 2014). In places where Islam had taken root before colonization, Koranic schools were established and operated side by side with these universities to help in skills development and knowledge transfer (Nyanchoga, 2014). For example, the grand mosque at Sankore and Timbuktu Mosque in ancient Mali in the 14th century, as well as the great Mosque of Jenne in Sudan in the middle ages all served as institutions of higher learning and skills acquisition (Nyanchoga, 2014). These important skills 
development centres and custodians of Afrikology were to be destroyed by the forces of colonialism that introduced an education and skills development system that was alien to African traditions, economic orientation and governance structures (Lulat, 2003; Mart, 2011).

The formal colonial era in SSA effectively began with Europe's 'scramble' and partitioning of Africa at the $1884-1885$ Berlin Conference (Nafukho \& Muyia, 2016). Following the partitioning and several wars of resistances that followed, much of SSA had by 1900 come under colonial rule led by Britain and France, but also included Germany, Belgium, Spain, Portugal, and Italy (Nafukho \& Muyia, 2016). These colonialists set about establishing colonial state systems and enthroning so-called 'formal' western education and skills development initiatives to help drive the nascent colonial state (Woldegiorgis \& Doevenspeck, 2013). It should be pointed out, however, that the early education and skills development enterprise in colonial SSA was exclusively dominated by missionaries, as the colonial government did not take part officially (Lulat, 2003; Ihenetu, 2003).

By the beginning of the $20^{\text {th }}$ century, colonial higher education had begun to take shape in SSA leading to the establishment of university colleges that were affiliated to major universities in the 'mother' countries (Woldegiorgis \& Doevenspeck, 2013). In 1827 Fourah Bay College in Sierra Leone and Potchefstroom University for Christian Higher Education in South Africa was founded by Church Missionary Society. Fourah Bay College was affiliated to Durham University in 1876 as an institution for training African clergymen and schoolmasters (Woldegiorgis \& Doevenspeck, 2013).

Many other teacher training schools and higher education institution followed afterward in Anglophone SSA, including the University of Cape Town (1829) and Stellenbosch University (1866) both in modern South Africa, Makerere University in 
Uganda (1922) and Egerton University in Kenya (1939) (Ihenetu, 2003). In the Francophone regions, these efforts dates to 1896 when France established a medical training institute in Tanarive in Madagascar, William Ponty Training School in Goree in Senegal in1903, and a medical training institute in Dakar in 1918. After the end of WWI1 more higher education institutions were established in SSA including University of Ghana (1948), the University of Ibadan in Nigeria (1948), Addis Ababa University in Ethiopia (1950) and the University of Zimbabwe (1952) (Lulat, 2003, Lulat, 2005).

Despite these modest developments, it should be recognized that the colonial state in SSA as elsewhere was a machinery of administrative control and domination, which was established to facilitate forceful subjugation and exploitation of colonialized societies. This objective was very much reflected in the aim of education and skills development in colonial SSA, which was limited in scope and content, and tailored mainly to serve the needs of the 'Whiteman' in Africa (Ashby, 1961). The colonialists needed interpreters, clerks and skilled native labour to help collect taxes and maintain law and order, and colonial education was tailored merely to meet these basic needs (Lulat, 2005). This helps explain why access to higher education was extremely limited to few individuals. It also accounts for why illiteracy rates were so high when most SSA countries gained independence in the late 1950s and early 1960s, so much so that only three percent of high school age students received secondary education in British colonies at independence, even as less than one-quarter of all professional civil service posts were held by Africans (Woldegiorgis \& Doevenspeck, 2013; Mart, 2011).

In all, the objective of colonial education in SSA was not to address the region's human capital and capacity needs or advance its socio-economic and human development. Instead, education was used as a tool for subjugating Africans and facilitating the smooth operations of the colonial state to ensure maximum exploitation. 
Educational programs, courses, and skills development initiatives were articulated to serve only colonial interests, thus detaching them from the people's historical past and their future needs.

\section{NHRD in postcolonial SSA}

Following the end of formal colonialism and the gaining of political 'independence' by most SSA countries in the 1960s from their European colonialists, many countries in the region had the desire to shape their future by localizing their public policies through what became known as 'Africanization' (Nafukho \& Muyia, 2016). As a development philosophy, Africanization recognizes that the availability of endogenous capacity is the key to national development. This philosophy provided the impetus for several SSA countries to invest heavily in education and skills building in a bid to advance the capabilities of their citizens in the immediate aftermath of the end of colonialism in the 1960s. The philosophy also helps explain why HRD became a national policy priority for many SSA countries in the postcolonial era. Indeed, between 1960 and 1999, national governments in SSA outperformed most other world regions in the growth of educational expenditure and enrolment (see UNESCO, 2015).

Public expenditure on education in SSA remains strong in contemporary SSA, increasing sevenfold over the past 30 years (UNESCO, 2018). On average, education absorbs about 15 percent of total public spending in SSA and nearly 5 percent of GDP, the largest spending ratios among developing regions (World Bank, 2018). This commitment to education means that more SSA children are in school today than ever, and primary completion rates have more than doubled in the region over the past halfcentury, while completion of secondary schooling and the number of those graduating from university have increased more than fivefold (see World Bank, 2018 for recent estimates). 
Several strategic policies geared towards improving education and skills development have also been initiated at both the regional and national levels. The African Union's (AU) fifty-year transformation plan - Agenda 2063, reflects Africa's aspirations for future generations premised on 'an integrated, prosperous and peaceful Africa, driven by its citizens and representing a dynamic force in the global arena' (AU, 2015). At the core of Agenda 2063, is the need to reposition education and training systems to develop the required human resources for a sustainable development rooted in African values (UNESCO, 2018). Drawing on experiences from two decades of education and lessons from other parts of the world, the AU Commission has developed the comprehensive Continental Education Strategy for Africa (CESA) 2016 - 2025 to achieve the ambitions of Agenda 2063 (AU, 2016). CESA proposes a holistic vision, integrating all sub-sectors of education and training systems while defining Africa's objectives and adapting and aligning the sustainable development goals with African's aspirations (UNESCO, 2018).

Similar efforts also exist at sub-regional levels. The Southern African Development Community (SADC) for instance, have initiated several policies aimed at improving the human resources of its 15 -member states. The Regional Indicative Strategic Development Plan (RISDP) and the SADC Protocol for Education and Training, give strategic direction and focus to future education and human resources development programs within SADC (Nafukho \& Muyia, 2016). These regional and sub-regional efforts are complemented further by national level initiatives, as governments in several SSA countries increasingly recognize the centrality of a skilled national workforce in advancing socio-economic and political development.

In many instances, the national policy agenda for education and skills development is encapsulated in the broader National Development Plans (NDP) of these 
countries, and this is a good development as it helps position NHRD as an essential activity for national development. The NDP of Nigeria (Vision 20:2020) and that of Kenya (Vision 2030), for instance, recognize HRD as the foundation for economic growth and equitable social development of its citizens. Education and skills building are highlighted as key social pillars of Kenya's Vision 2030, while Nigeria's Vision 2020 policy document (2009: 2), states that it intends to 'make efficient use of human and natural resources to achieve rapid economic growth.'

Several other countries in the region have also developed specific national HRD plans, including Botswana (NHRD Strategy 2009 - 2022), Namibia (NHRD Plan 2010 - 2025) and HRD Strategy for South Africa (HRD-SA) 2010 - 2030, amongst others. While it has to be acknowledged that there are differences in the overarching objectives, philosophies and governance models of these national initiatives, the policy thrusts relating to NHRD are cast in similar broad imperatives including: empowering people through education and training, improving access to education, improving technical and vocational education, modernizing the curricula and developing higher education infrastructure (ADB, 2018). Other imperatives include empowering women and youth, tackling the HIV/AIDS challenge, promoting the welfare of children and strengthening social safety nets (UNESCO, 2018).

Given these initiatives and considerable investments in education and skills development, it would appear that SSA as a region is on the right track in its efforts to improve the skills and capabilities of its people. However, the evidence suggests that this might not be the case. Indeed, too many people in too many SSA countries do not have the foundational skills they need to thrive and prosper in an increasingly competitive global economy (World Bank, 2018). This development has adversely affected the level of human capital development and utilization in SSA, further 
constraining developmental prospects of the region. Several countries in SSA are also experiencing a digital divide and many have low skilled population which signifies a lack of readiness for the emerging knowledge-driven digital economy, hence the need to pay closer attention to the human resource challenges affecting the region.

\section{The nature and dynamics of contemporary NHRD and skills challenges in SSA}

The NHRD challenges in SSA range from securing skilled and capable people, dealing with the deficiencies of the education system to navigating the changing demographics of an increasingly international mobile labour force (UNDP, 2017, ADB, 2018). Despite the expansion in the education system, the level of literacy in SSA is still comparatively low when compared to other DCs and emerging markets (UNDP, 2018). Indeed, according to the World Bank (2018), SSA's human resources is the least skilled globally, despite having the youngest population of any region of the world, $60 \%$ of whom are under 25 (Leopold et al., 2017). SSA pupils also regularly rank at the bottom of international comparisons leading to adverse impacts on all future skill investments (UNESCO, 2011; UNESCO, 2015). The World Bank (2018), estimates that the literacy rates of the adult population are below 50 percent in many SSA countries, and functional literacy and numeracy are even lower.

One reason for these constraints stems from weaknesses in the education system. The schooling system and skills development in many SSA states are in considerable disarray, and according to UNESCO (2015), teacher quality and infrastructural deficiencies are big problems. The Vocational training landscape has equally not been effective due to several attitudinal and systemic reasons, which according to UNESCO (2011) includes the fact that education systems in many SSA countries favour general education above vocational education, lack of appropriate funding, outdated curricula, 
poor teacher quality, and quality assurance issues. There is also the issue of a lack of recognition of skills acquired in the informal sector.

Although the region has been witnessing impressive growths in the number of its university graduates in recent times (see UNESCO, 2015 for recent estimates), the problem, however, is that the numbers which are 'industry-ready' and technologically savvy are alarmingly small (Ekuma, 2015). It appears that the educational system of many SSA countries tends to produce graduates who lack job skills for employment than those the economy requires to remain vibrant - a skills gap.

The mismatch between human resource needs and existing skills in the region means that there is not enough skilled talent pool to recruit from, with most workers lacking in basic skills, especially technical and cognitive skills. This explains why organizations in most parts of the region increasingly find it challenging to recruit and retain the requisite skilled human resource - a talent crunch (UNDP, 2013). A Schoolto-Work Transition survey in a few countries in the region (Benin, Liberia, Malawi, and Zambia) undertaken by Elder and Koné (2014) for the International Labour Organization (ILO) helps illustrate this point. The survey highlights that technical, interpersonal and higher-order cognitive skills were significant issues constraining the employment prospects of young people aged 15 to 29 years. The problem of a skills gap is worrying considering that it can lead to decreased industrial capacity utilization as well as create structural unemployment, with its associated threats of social insecurity by jobless youths.

The pertinent question to ask at this juncture is a simple but profound one: after so many policy initiatives and investment aimed at improving the education and skills development in several SSA countries, why have all the efforts not resulted in a sufficient and adequate turnaround? Illuminating this question is admittedly not an easy 
task and requires an appreciation that NHRD is a complex process, which is usually influenced by several contextual dynamics, including history, politics, institutions, culture, dominant discourses and several others. Several studies (e.g., Johanson \& Adams, 2004; Oketch, 2007; Oketch, 2016; UNESCO, 2011; Ansu \& Tan, 2012, etc.), have already extensively discussed the political, socio-economic, cultural, structural and institutional challenges to education and skills development in SSA, and there is no need rehearsing these issues in this current piece. It suffices to add here however that the current challenges to NHRD in SSA, especially education and skills development also has historical and institutional dimensions, engendered mainly by the nondeconstruction of what scholars (e.g., Ayee, 2008) label 'migrated structures' after independence in most SSA countries.

\section{Colonialism's enduring legacy and the role of 'migrated' institutional structures}

Institutions are socially constructed systems that are embedded in identities and belongings which are often country or context specific (North, 1992). As Hayden (2008: 2), argues 'institutions are ubiquitous but not universal,' and emerge 'from the store of cultural values and norms that a given society treasures.' In SSA however, educational and other skills development institutions, like most other institutions in the region did not emerge in this manner. Instead, there are part of inherited and migrated colonial structures (Ayee, 2008). The past five decades since most SSA gained 'political' independence, have, however, shown that these migrated structures and institutions were inadequately positioned to effectively perform the functions they were designed for in their originating context. This is so because they were mostly not accompanied by the values and norms that motivate institutions to work within its context (Hayden, 2008). 
Education institutions have always played roles assigned to it by governments and societies. In SSA however, these roles were constructed by imperialist agents and the colonial state, who used education as a tool for the realization of economic exploitation and socio-cultural control, instead of the development of Africans (Nyanchoga, 2014; Woldegiorgis \& Doevenspeck, 2013). In a bid to reinforce the purpose of education as a process of colonial control, the few higher education institutions created in colonial SSA were merely extensions of universities in the metropolis and were utilized as instruments of domination and colonization, instead of citadels of learning and scientific renaissance.

The University of Ibadan in Nigeria, for instance, was established as a college of the University of Oxford in 1948 and remained so until late 1963, while the foremost Fourah Bay College was an affiliate of Durham University in the United Kingdom (Nyanchoga, 2014). As already highlighted, this development ensured that the curriculum and programme contents of these institutions were tailored to promote the colonial agenda and had very little relevance for the enlightenment of Africa and its people. African traditional learning spaces, local institutions, languages, religions, and cultures were also deliberately portrayed as backward and uncivilized by colonial powers as a pretext to further subjugate the people in order to advance the colonial agenda (Woldegiorgis \& Doevenspeck, 2013).

The implication of this total control was the loss of history and identity by most Africans, even as the institutional roots of postcolonial African states became structurally dependent on colonial values and systems. This legacy of colonialism has created foundational problems that mitigate against the establishment of effective and efficient institutions for education and skills development in post-independence SSA (Nyanchoga, 2014). This is especially so, given that colonial policies and institutions 
locked education and skills development into path-dependent trajectories for long periods, ensuring that their structuring effects persisted long after countries gained political 'independence' (Schwanen, 2018). It is plausible to suggest that this development has contributed significantly to the ineffectiveness of current NHRD institutions, systems, and policies in contemporary SSA.

The effects of colonialism and coloniality on education and skills development in SSA are not limited to policies and institutions. Equally important have been the impacts on the 'expert' and general knowledge about NHRD that are generated and held by academics, policymakers and practitioners in SSA and other postcolonial contexts. As earlier mentioned in this current piece, prevailing knowledge about NHRD in a global context, including SSA are deeply influenced by hegemonic Western ideas that are assumed to be more or less universally applicable (Lee, 2017). It remains unclear, however, the extent to which interventions underpinned by western knowledge have been beneficial to SSA countries, especially given the many critical developmental issues currently confronting the region, including escalating poverty levels, growing inequalities, and massive youth unemployment. There is a sense to argue, therefore, that the appeal to 'western' knowledge lies more in power and politics than in its ability to generate sufficiently context-sensitive understandings of diverse and complex developmental systems and practices in specific sites across the world.

This argument reinforces the utility of a postcolonial interpretation of NHRD as well as the need for a critical reflection and rethinking of expert knowledge about the concept. Central to this rethinking agenda is the need to reimagine the geopolitical power relations between North and South, as well as a philosophical and epistemological shift in the ways that knowledge is produced and disseminated (Syed \& Metcalfe, 2017; Tilky, 1999). Such reflections and indeed wider decolonization of 
expert knowledge about NHRD is long overdue because it will open up different ways of thinking not only about education and skills development policy but also about the entire development process. It is against this backdrop therefore, that the paper suggests some ideas about how expert knowledge about NHRD theory and practices might be decolonized and made inclusive, thereby contributing to a tradition of paradigmatic critique in HRD theorizing with roots in feminist and poststructuralist theories (e.g. Elliot \& Turnbull, ed., 2004; Stewart, Rigg \& Trehan, 2007; Bierema \& Callahan, 2014; Metcalfe, 2011; Valentin, 2006; Sambrook, 2008, etc.).

\section{Rethinking NHRD: towards an inclusive global knowledge}

It is essential to construct and promote a global knowledge about all dimensions of HRD, including NHRD, not only for reasons discussed above but importantly because of how it can shape the subjectivities open to HRD researchers and professionals. Some HRD experts might frown at the prospect of a global HRD knowledge, especially because of the fear that it might lead to a dearth of the historical and geographical particularity that is required in examining NHRD systems and practices in postcolonial and other contexts. These concerns are not entirely unfounded, and in order to assuage these fears, it is essential to recognize the distinctions between the global and its formation - i.e., globalization and the idea of global knowledge.

As stated previously, globalization is the uneven process of continuing integration of countries, through an increasing flow of goods, services, capital, labour and ideas (Stiglitz, 2002). While this process admittedly generates many economic and other benefits, one of its main limitation as already highlighted by several critics (e.g. Gill, 2008; Castells, 2011; Ferguson, 2005; Thompson, 2005; Ashenfelter et al., 2018, etc), is that it assumes arbitrarily that norms, values, and processes are valid always and everywhere, irrespective of time, place and history. Globalization attempts to 
universalize westernization as the ideal model of development, and this is very problematic because it does not allow for the construction of global knowledge about NHRD in SSA as elsewhere. 'Global knowledge' on the other hand, is about inclusivity and diversity. It involves viewing and understanding the entire world as an interconnected space and seeks to highlight an individual's, a society's, or a culture's place in it by recognizing and valuing different philosophies, opinions, and voices (Syed et al., 2018). Global knowledge is transferable and enables us to adopt 'best practice' practices in local situations.

The need for global knowledge in NHRD theory and practice becomes selfevident when success stories of NHRD policies in particular places, for instance, lifelong learning in Singapore and South Korea are easier than ever to adapt and replicate elsewhere due to the global diffusion of public policies (Dobbin, Simmons \& Garrett, 2007). Policy adaptation or replication is of course not an easy task and is often influenced by several contextual realities (Saetren, 2009), yet it is possible to create a truly global knowledge about NHRD that is both inclusive and responsive to local conditions. A first step towards achieving this is to deconstruct 'western' concepts, theories and practices that have become the theoretical foundations for expert knowledge about HRD across the world. It also involves reimagining the methodological practices in HRD and developing new research agendas and approaches that promote inclusivity and pluralism.

\section{Deconstructing and decolonizing HRD}

Deconstructing and decolonizing HRD is not a straightforward task. However, a reasonable starting point is to critically reinterpret both the histories and effects of NHRD in postcolonial contexts, including SSA. This implies the re-examination of the origins of HRD concepts, theories and methodological practices with a view of 
resituating them within their proper historical contexts, given that most social science theories and practices, including HRD, are often not purely 'western', but are a complex hybrid of ideas that have been influenced by colonial configurations (Lee, 2017; Schwanen, 2018; Adebanwi, 2016). This historicity needs to be complemented by a critical analysis of the consequences and implications of the utilization of 'western' HRD concepts, theories and methodological practices across postcolonial contexts - as not all of these interventions have produced positive outcomes.

Deconstructing the existing knowledge about HRD or any other social science for that matter, therefore, entails a double movement. It involves the need to decolonize and disrupt existing theories and practices on the one hand; and the need to develop new concepts, theories and methodological practices that encourage critical and inclusive dialogues on the other hand (Schwanen, 2018). This double movement is vital because there is no point in a postcolonial revenge (Schwanen, 2018), in the sense of full-scale rejection and discarding of western concepts, theories and practices. As Schwanen (2018) points out, many of these theories and practices, despite their flaws, have become the foundation of most modern social science. Some of these theories/concepts, for instance, have become indispensable to our understanding of NHRD systems and practices beyond the West and continue to generate significant effects through the practices and policies/interventions they underpin and legitimize (Lee, 2017).

\section{Reimagining methodological practices and constructing 'new' knowledge}

From what has been said so far, it should be evident that an inclusive and global knowledge of HRD systems and practices remain possible and desirable. However, inclusivity in the production of expert and general knowledge about HRD, especially NHRD does not have to be a product of westernization nor driven by universalization (Syed et al., 2018). Indeed, such knowledge needs to be decolonized and decoupled 
from both the hegemony of westernization and the trap of universalization (Adebanwi, 2016). Instead, a global HRD knowledge should be rooted in particular modes of generalization informed by an inclusive dialogue, epistemological plurality and historical and cultural sensitivity (Lee, 2017). Achieving this delicate balance is of course not an easy task. It requires the construction of 'new' knowledge systems by incorporating non-Western concepts, theories and methodological approaches in both traditional HRD studies and most of the 'critical turn' - a body of literature that explores the constructed nature of HRD theory and practice, including the implications of ideas, languages, identities, culture and history, but which are also primarily embedded in western thought (e.g. Poell et al., 2015; Sambrook, 2006; Lawless et al., 2010; Rigg \& Trehan, 2002; Francis, 2007, etc.).

The construction of new knowledge through symbiotic and respectful engagement with extant alternatives has the potential of creating bottom-up generalizations and mid-range theories and practices that might provide new insights and better understanding of the NHRD process in vastly disparate parts of the world. An exciting line of enquiry that helps illustrate this possibility and which requires further elaboration is the emerging dialogue informed by the capability approach (Sen, 1985; Nussbaum, 2011) which positions skills and capabilities as the material base to everyday lives (Robeyns, 2006). For many inhabitants in SSA, the capability and freedom to do something - even informally, such as rural farming or street hawking, for example, are the mainstay of their livelihoods. Yet, these large groups are often overlooked and excluded in the analysis of how skills development and national education policies are constructed and implemented in much of SSA. This exclusion needs to be urgently addressed. It is crucial therefore, for HRD researchers to try to 
always give a voice to people whose perspectives are not often captured in current accounts about HRD such as marginalized groups and informal workers.

\section{Conclusion and a research agenda}

This paper has critically explored the nature and dynamics of NHRD in SSA, highlighting how the region's current human resource challenges are linked to colonialism and coloniality. In doing so, the essay identified dysfunctional elements in the migrated institutional structures that underpin education and skills development efforts in contemporary SSA and discussed various areas of change that could help to decolonize NHRD theory and practice and promote global knowledge about the subject. As the analyses in this paper have shown, addressing the human resource challenges in SSA requires not just changes in policies and strategies, but also a rethinking of the fundamental ethos underpinning HRD. This implies deconstructing the concept and opening it up to new dialogues through methodological reimagination and construction of 'new' inclusive knowledge.

Rethinking HRD and decolonizing the concept, is especially crucial for transitioning and postcolonial contexts like SSA, which have often been at the periphery of the debates on the nature of NHRD and its knowledge production. This development perhaps, helps explain why key actors in SSA have consistently interpreted skills development and NHRD issues within the context of Western analogy, and many practices mirror policies and strategies emanating from Europe and the United States. While there is nothing wrong in mirroring global 'best practices,' the problem, however, is that most of these 'borrowed' policies often do not reflect local needs. As previously stated, this might account for why several NHRD efforts in many SSA countries have persistently failed to address the burgeoning human resource needs in the region, and this has serious developmental consequences for the region (World Bank, 2018). 
As the global focus shifts to the sustainable development goals (SDGs) and on how to create more effective states in postcolonial contexts, it has become imperative for the human resources in SSA to be abreast of new ideas, techniques, and new planning and implementation methods (Ekuma, 2015). The urgent need for SSA countries to strengthen their institutional frameworks that support good governance and social development, adds a critical dimension to this imperative (Syed et al., 2018). These demands place greater urgency on SSA countries to address the skills challenges currently faced by the region (ADB, 2018; World Bank, 2018). These demands are of course not lost on national governments in SSA, and the belief in NHRD as a necessity for rapid development has been a dominant feature in the region's development history. NHRD continues to be a major priority area in SSA's contemporary political economy, as governments and development partners continue to acknowledge the critical role of skilled human resources in the adjustment of inequalities, poverty alleviation and improved service delivery (UNDP, 2013).

However, despite this realization and considerable investments towards improving human resource capabilities in SSA, the region's skills deficit remains the worst compared to other parts of the world (World Bank, 2018). Several multidimensional factors admittedly contribute to this unfortunate scenario, but as this paper has shown, it seems that at the root of the problem is SSA's colonial experience and inherited colonial structures, which has created foundational problems for the evolution of appropriate institutional arrangements for effective NHRD in postcolonial SSA. As argued here, this is especially so because colonial policy and institutions locked education and skills development into path-dependent trajectories for extended periods (Schwanen, 2018), ensuring that their structuring effects continue to persist in SSA's contemporary body polity. Apart from its impacts on policies and institutions, 
colonialism and coloniality have also ensured that the accepted 'expert' and general knowledge about NHRD in SSA and other postcolonial context remains deeply influenced by hegemonic Western ideas, to the detriment of other promising alternatives. This development helps explain why unproven dominant assumptions and potentially inappropriate NHRD policies/interventions persist; and underscores the need for SSA to be at the centre of creating 'new' expert/general knowledge about NHRD. It is crucial, therefore, for scholars to reframe the discourse on NHRD and promote a culturally and context-sensitive understanding of how education and skills development can be furthered in developing contexts, including SSA with their unique development challenges and institutional constraints. Central to this agenda is a concern to 're-narrativize' (Hall, 1996) the global NHRD story in a way that places historically marginalized parts of the world at the centre, rather than at the periphery of the education and skills development debates. Such a critique should also be concerned primarily with the continuing impacts of European colonialism on education systems in SSA and other postcolonial contexts. It should also focus on the issues of race, culture, language, as well as other forms of social stratification including class and gender in postcolonial contexts. Some of the questions that need urgent and critical attention include: what practices and approaches do extant HRD concepts, theories and practices render visible and thinkable? Which power relations are enacted through their adoption and utilization?

There is a need for researchers to undertake more research and engage in more empirical and conceptual clarifications of the issues and questions highlighted above, especially the impacts of coloniality on NHRD knowledge creation, dissemination, and utilization as well as the critical links between agents, structures and institutions in the NHRD process in postcolonial contexts. Methodologically, therefore, a future research 
agenda needs to examine the complex interplay between these contextual variables by adding sophisticated comparative research designs, perhaps of a country or regional case studies. It is also necessary for future studies to further explore the implications of inherited colonial institutional structures for those links, with a particular focus on their relevance to the assumptions that have historically shaped national HRD policies in transitioning and postcolonial contexts. 


\section{References}

Adebanwi, W. (2016). Rethinking knowledge production in Africa. Africa: The Journal of the International African Institute, 86(02): 350-353.

African Development Bank. (2018). African development outlook. Abidjan: African Development Bank. Retrieved from https://www.afdb.org/fileadmin/uploads/afdb/Documents/Publications/African_Ec onomic_Outlook_2018_-_EN.pdf [Accessed 21 September 2018].

Alagaraja, M. \& Githens, R. (2016). Capacity and capability building for national HRD. Human Resource Development Review, 15(1): 77-100.

Alagaraja, M., \& Wang, J. (2012). Development of a national HRD strategy model: Cases of India and China. Human Resource Development Review, 11(4): 407-429.

Ansu, Y., \& Tan, J. P. (2012). Skills development for economic growth in Sub-Saharan Africa: a pragmatic perspective. Good Growth and Governance in Africa: Rethinking Development Strategies, 462-497.

Arthur-Mensah, N., \& Alagaraja, M. (2018). Examining training and skills development of youth and young adults in the Ghanaian context: an HRD perspective. Human Resource Development International, 21(5): 493-508.

Ashby, E. (1961). Patterns of universities in non-European societies. London: School of Oriental and African studies.

Ashenfelter, O., Engle, R. F., McFadden, D. L., \& Schmidt-Hebbel, K. (2018). Globalization: contents and discontents. Contemporary Economic Policy, 36(1): 29-43.

Ayee, J.R.A. (2008). Reforming the African public sector: Retrospect and prospects. 


\section{Dakar: CODESRIA.}

Bierema, L. L., \& Callahan, J. L. (2014). A framework for critical HRD practice:

Transforming HRD. Advances in Developing Human Resources, 16 (4): 429-444. doi:10.1177/ 1523422314543818.

Biney, A. (2017). Decolonial turns and development discourse in Africa: Reflections on masculinity and pan-Africanism. Africanus: Journal of Development Studies, 43(2): 78 .

Carl, J. (2006). Disrupting preconceptions: Postcolonialism and education. Comparative Education Review, 50(1): 154-156. doi:10.1086/501145

Castells, M. (2011). The Rise of the network society. 2nd ed. Somerset: Wiley.

Chakrabarty D (2000). Provincializing Europe: Postcolonial thought and historical difference. Princeton, NJ: Princeton University Press.

Cho, E. S., \& McLean, G.N. (2004). What we discovered about NHRD and what it means for HRD. Advances in Developing Human Resources 6 (3): 382-393. doi:10.1177/ 1523422304266090.

Collins, J., Zaretsky, J \& Tkenkho, O. (2017). An integrated model of national HRD and critical HRD: considering new possibilities for HRD. Human Resource Development International 20 (3): 236-252. doi:10.1080/13678868.2016.1258913.

Cunningham, P. W., S. Lynham, \& Weatherly, G (2006). National human resource development in transitioning societies in the developing world: South Africa. Advances in Developing Human Resources 8: 162-183. 
doi:10.1177/1523422305283059.

Dastile, N. P., \& Ndlovu-Gatsheni, S. J. (2013). Power, knowledge and being: Decolonial combative discourse as a survival kit for pan-Africanists in the 21 st century. Alternation, 20(1): 105-134.

Dauda, R. O. (2010). Role of human capital in economic development: An empirical study of Nigerian case. Proceedings of Oxford Business and Economic Conference Program, Oxford University, (June 28 - 29).

De-Silva, S. (1997). Human resources development for competitiveness: A priority for employers. Paper presented at the ILO Workshop on Employers' Organizations in Asia-Pacific in the Twenty-First Century, Turin, Italy, 5-13 May.

Dobbin, F., Simmons, B., \& Garrett, G. (2007). The global diffusion of public policies: Social construction, coercion, competition, or learning? Annual Review of Sociology., 33: 449-472.

Eade, D. (2010). Capacity building: who builds whose capacity? In Andrea, C. \& Deborah, E. Deconstructing development discourse buzzwords and fuzzwords. GB: Oxfam.

Edwards, T. \& Rees, C. (2006). International human resource management. Harlow: Financial Times Prentice Hall.

Ekuma, K. (2015). Rethinking civil service human capital in a developing context: A capability development perspective. $\mathrm{PhD}$ Thesis. The University of Manchester.

Elder, S., \& Koné, K. S. (2014). Labour market transitions of young women and men in sub-Saharan Africa. Geneva: ILO. 
Elliott, C., \& Turnbull, S. (Eds.). (2004). Critical thinking in human resource development. London: Routledge.

Ferguson, N. (2005). Sinking globalization. Foreign Affairs, 84: 64-77.

Francis, H. (2007). Discursive struggle and the ambiguous world of HRD. Advances in Developing Human Resources, 9(1): 83-96.

Fukuyama, F. (1993). The end of history and the last man. New York: Harper Perennial.

Garavan, T., Wang, J., Matthews-Smith, G., Nagarathnam, B., \& Lai, Y. (2018). Advancing national human resource development research: suggestions for multilevel investigations. Human Resource Development International, 20 (4): 268 $-281$.

Gill, S. (2008). Power and resistance in the new world order. $2^{\text {nd }}$ ed. Basingstoke, Hampshire: Palgrave-Macmillan.

Goldin, I. \& Reinhert, K. (2012). Globalization for development: Meeting new challenges. Oxford: Oxford University Press.

Hall, S. (1996). When was the postcolonial? Thinking at the limit, in I. Chamber \& L. Curtis (eds.) The post-colonial question: common skies, divided horizons. London: Routledge, 242- 260.

Hasler, M. G., Thompson, M. D., \& Schuler, M. (2006). National human resource development in transitioning societies in the developing world: Brazil. Advances in Developing Human Resources, 8(1): 99-115.

Hayden, G. (2008). Institutions, power and policy outcomes in Africa. The Africa Power and Politics Programme (APPP) Discussion Paper No. 2. Retrieved from 
http://www.institutions-africa.org/filestream/20080623-discussion-paper-2institutions-power-and-policy-outcomes-in-africa-goran-hyden-june-2008 [Accessed 02 September 2018].

Hickling-Hudson, A., Matthews, J., \& Woods, A. (2004). Education, postcolonialism and disruptions. Disrupting preconceptions: Postcolonialism and education, 1-16.

Jack, G., \& Westwood, R. (2009). International and cross-cultural management studies: A postcolonial reading. Springer.

Jackson, T. (2004). Management and change in Africa: A cross-cultural perspective. London: Routledge.

Johanson, R. K., \& Adams, A. V. (2004). Skills development in sub-Saharan Africa. The World Bank.

Kenny, S. \& Clarke, M. (2010). Introduction. In S. Kenny. \& M, Clarke (eds.). Challenging capacity building: comparative perspectives. Houndmills, Basingstoke: Macmillan: $3-20$.

Kim, N. (2012). Societal development through human resource development: Contexts and key change agents. Advances in Developing Human Resources 14(3): 239-250. doi:10.1177/1523422312446054.

Lawless, A., Sambrook, S., Garavan, T. and Valentin, C. (2011). A discourse approach to theorising HRD: Opening a discursive space. Journal of European Industrial Training, 35(3): 264-275.

Lee, M. (2017). HRDI, colonization, and post-truth politics. Human Resource Development International, 20(5): 350-360. 
Leopold, T. A., Ratcheva, V. \& Zahidi, S. (2017). The future of jobs and skills in Africa Preparing the region for the fourth industrial revolution: Geneva: World Economic Forum.

Lulat, Y. G. (2003). The development of higher education in Africa: A historical survey. In D. T. Altbach, \& D. T. Altbach (Eds.), African higher education: An international reference handbook: 15-31. Bloomington: Indiana University Press.

Lulat, Y. G.-M. (2005). A history of African higher education from antiquity to the present. Westport CT: Praeger Publishers.

Maldonado-Torres, N. (2007). On coloniality of being: contributions to the development of a concept. Culture Studies, 21(2-3): 240 - 270.

Marquardt, M., \& Berger, N. O. (2003). The future: Globalization and new roles for HRD. Advances in Developing Human Resources, 5(3): 283-295.

Mart, C. T. (2011). British colonial education policy in Africa. International journal of English and literature, 2(9): 190-194.

McGuire, D. (2014). Human resource development, $2^{\text {nd }}$ ed. Thousand-Oaks, CA: Sage.

McLean, G. N. (2004). National human resource development: What in the world is it?" Advances in Developing Human Resources 6 (3): 269-275. doi:10.1177/1523422304266086.

McLean, G. N. (2006). National human resource development: A focused study in transitioning societies in the developing world. Advances in Developing Human Resources 8 (1): 3-11. doi:10.1177/15234223052830548.

McLean, G. N., \& McLean, L. (2001). If we can't define HRD in one country, how can 
we define it in an international context? Human Resource Development International 4 (3): 313-326. doi:10.1080/13678860110059339.

McLeod, J. (2013). Beginning postcolonialism. Oxford University Press.

Metcalfe, B. D. (2011). Women, empowerment and development in Arab Gulf States: a critical appraisal of governance, culture and national human resource development (HRD) frameworks. Human Resource Development International, 14(2): 131-148.

Miller, C. (2010). Developing capacities and agencies in complex times. In S. Kenny. \& M, Clarke (eds.). Challenging capacity building: Comparative perspectives. Houndmills, Basingstoke: Macmillan: $21-40$.

Moncrieffe, J. \& Luttrell, C. (2005). An analytical framework for understanding the political economy of sectors and policy arenas. England: Overseas Development Institute.

Nafukho, F. M., \& Muyia, H. M. (2016). Human Resource Development in SubSaharan Africa. In Global Human Resource Development: 143-159. Routledge.

Ndhlovu, F. (2016). A decolonial critique of diaspora identity theories and the notion of superdiversity. Diaspora Studies, 9(1): 28-40.

Nkomo, S. (2011). A postcolonial and anti-colonial reading of 'African' leadership and management in organization studies: tensions, contradictions and possibilities. Organization, 18(3): 365-386.

North, D. (1992). Institutions, institutional change and economic performance, Reprint ed. Cambridge: Cambridge University Press.

Nyanchoga, S. A. (2014). Politics of knowledge production in Africa: A critical 
reflection on the idea of an African university in sustainable

development. European Law and Politics Journal, 1(1): 37-55.

Oh, H., Seo, D., Yoo, S., \& Kim, J. (2017). Analysis of strengths and weaknesses in the National Human Resource Development systems of BRICS. Human Resource Development International, 20(4): 268-281.

Oketch, M. (2007). To vocationalise or not to vocationalise? Perspectives on current trends and issues in technical and vocational education and training (TVET) in Africa. International Journal of Educational Development, 27(2): 220-234.

Oketch, M. (2016). Financing higher education in sub-Saharan Africa: some reflections and implications for sustainable development. Higher Education, 72(4): 525-539.

Otoo, S., Agapitova, N., Gold, J. \& Fisher, S. (2009). The need for a conceptual and results oriented framework in capacity development: discussion of a new approach. Capacity Development Briefs, 31.

Poell, R., F. Tonette, S. Rocco., \& Gene, L. (2015). The Routledge companion to human resource development. London: Routledge.

Prakash, G. (1994). Subaltern Studies as Postcolonial Criticism. The American Historical Review, 99(5): 1475.

Rigg, C. \& Trehan, K. (2002). Do they or don’t they? A comparison of traditional and discourse perspectives of HRD in SMEs. Education + Training, 44(8/9): 388-397.

Rigg, C., Stewart, J. \& Trehan, K. (eds.) (2007). Critical human resource development: beyond orthodoxy. Edinburgh: Pearson Education Limited.

Rizvi, F., Lingard, B. and Lavia, J. (2006). Postcolonialism and education: negotiating a 
contested terrain. Pedagogy, Culture \& Society, 14(3): 249-262.

Robeyns, I. (2006). Three models of education: Rights, capabilities and human capital. Theory and Research in Education, 4(1): 69-84.

Saetren, H. (2009). Explaining radical policy change against all odds: The role of leadership, institutions, program design and policy windows, 53-72 in J. A. Raffel, P. Leisink and A. E. Middlebrooks (eds.) Public sector leadership: international challenges and perspectives. Cheltenham, UK: Edward Elgar.

Said, E. (2003). Orientalism. London: Penguin.

Sambrook, S. (2006). Management development in the NHS: nurses and managers, discourses and identities. Journal of European Industrial Training, 30(1): 48-64.

Sambrook, S. (2008). Critical HRD: A concept analysis. Personnel Review, 38(1): 6173.

Samoff, J. (1999). Institutionalizing international influence. In R. Arnove \& C. Torres (Eds.), Comparative education: The dialectic of the global and the local, 51-90. Lanham, MD: Rowman \& Littlefield.

Schwanen, T. (2018). Towards decolonised knowledge about transport. Palgrave Communications, $4(1)$.

Sen, A. K. (1985). Commodities and capabilities. Oxford: Oxford University Press.

Stiglitz, J. E. (2002). Globalisation and its discontents. New York: W.W. North.

Strongman, L. (2014). Postcolonialism and international development studies: a dialectical exchange? Third World Quarterly, 35(8): 1343-1354. 
Syed, J., \& Metcalfe, B. D. (2017). Under western eyes: A transnational and postcolonial perspective of gender and HRD. Human Resource Development International, 20(5): 403-414.

Syed, J., Metcalfe, B., Ali, F. \& Ekuma, K. (2018). Critical perspectives of HRD and social transformation in sub-Saharan Africa. Human Resource Development International, 21(5): 391-405.

The African Union (AU) Commission. (2015). Agenda 2063 - The Africa we want: A shared strategic framework for inclusive growth and sustainable development. Addis Ababa: AU Commission.

The AU Commission (2016). Continental education strategy for Africa 2016 - 2025 (CESA 16-25). Addis Ababa: AU Commission.

The World Bank. (2018). World development report - learning to realize education's promise. Washington: The World Bank

Thompson, G (2005). The limits of globalization. In Debating globalization. Held D (ed.). Cambridge: Polity.

Tikly, L. (1999). Postcolonialism and comparative education International Review of Education, 45 (5/6): 603-621.

Tikly, L. (2001). Globalisation and education in the postcolonial world: Towards a conceptual framework. Comparative education, 37(2): 151-171.

UNDP. (2013). Human Development Report - The Rise of the South: Human Progress in a Diverse World. New York: UNDP.

UNDP. (2018). Human Development Report: International Human Development 
Indicators. New York: UNDP.

UNESCO (2011). Financing education in Sub-Saharan Africa meeting the challenges of expansion, equity and quality. Montreal, Quebec: UNESCO Institute for Statistics.

UNESCO (2018). Unpacking Sustainable Development Goal 4: Education 2030 (SDG4-education 2030 coordination). Retrieved from http://www.education2030africa.org/index.php/en/sdg4-education-2030 [Accessed 21 September 2018].

United Nations Development Programme (UNDP) (2017). Tracking progress on Agenda 2063 and the Sustainable Development Goals. New York: UN.

United Nations Educational, Scientific and Cultural Organization (UNESCO). (2015). Education for all global monitoring report 2015 (Regional overview: Sub-Saharan Africa). Retrieved from http://unesdoc.unesco.org/images/0023/002325/232577E.pdf [Accessed 14 September 2018].

United Nations General Assembly. (1995). Sustainable development and international economic cooperation: Human resource development (Report of the SecretaryGeneral A/50/330). Retrieved from http://www.un.org/documents/ga/docs/56/a56162.pdf [Accessed 20 October 2018].

Valentin, C. (2006). Researching human resource development: emergence of a critical approach to HRD enquiry. International Journal of Training and Development, 10(1): 17-29.

Valentin, C. (2006). Researching human resource development: emergence of a critical approach to HRD enquiry. International Journal of Training and 
Development, 10(1): 17-29.

Woldegiorgis, E. T., \& Doevenspeck, M. (2013). The changing role of higher education in Africa: A historical reflection. Higher Education Studies, 3(6): 35.

Young, R. J. (2009). What is the Postcolonial? ARIEL, 40(1): $13-25$. 